\title{
AGAINST INTERPRETIVE SUPREMACY
}

\author{
Saikrishna Prakash* and John Yoo**
}

The People Themselves: Popular Constitutionalism and JUdiCIAL REVIEW. By Larry D. Kramer. New York: Oxford University Press. 2004. Pp. xii, 363. Cloth, $\$ 29.95$.

Many constitutional scholars are obsessed with judicial review and the many questions surrounding it. ${ }^{1}$ One perennial favorite is whether the Constitution even authorizes judicial review. Another is whether the other branches of the federal government must obey the Supreme Court's interpretation of the Constitution and what, if anything, the other branches must do to execute the judiciary's judgments. Marbury v. Madison ${ }^{2}$ has been a full-employment program for many constitutional law scholars, including ourselves.

Larry Kramer, the new Dean of Stanford Law School, shares this passion. He has devoted roughly the last decade of his career, with two lengthy law review articles ${ }^{3}$ and a half a dozen shorter pieces, to these questions. In these works, he has consistently advanced a two-pronged argument against judicial review and judicial supremacy. First, Kramer has claimed that while the Founders explicitly sanctioned judicial review of state constitutions and laws, they never intended courts to judge the constitutionality of federal legislation. Given the novelty and relative obscurity of judicial review in 1789 , the Founders would never have authorized judicial review of federal statutes. Second, Kramer

* Professor of Law, University of San Diego. B.A. 1990, Stanford; J.D. 1993, Yale. - Ed.

* Professor of Law, University of California (Boalt Hall); Visiting Scholar, American Enterprise Institute. A.B. 1989, Harvard; J.D. 1992, Yale. - Ed. Thanks to John McGinnis and Larry Alexander for helpful conversations.

1. In the interest of clarity, we use "judicial review" rather narrowly, as only encompassing the power of judges to decide the meaning of a constitution in the course of hearing a case. Hence, when a litigant claims that some statute violates the federal Constitution, the judge may decide for herself whether the statute actually does violate the Constitution. Given our narrow meaning of judicial review, nothing need follow from the judiciary's reading of the Constitution. In particular, our definition says nothing about what, if anything, other people must do either with the judiciary's constitutional interpretations or with the resulting judgments.

\section{5 U.S. (1 Cranch) 137 (1803).}

3. See Larry D. Kramer, Putting the Politics Back into the Political Safeguards of Federalism, 100 Colum. L. REV. 215 (2000); Larry D. Kramer, The Supreme Court, 2000 Term - Foreword: We the Court, 115 HARV. L. REV. 4 (2001) [hereinafter Kramer, We the Court]. 
has insisted that rather than crowning the judiciary supreme in constitutional interpretation, the Constitution actually took for granted that the people were the final arbiters of the Constitution's meaning and that they would influence and discipline the federal branches through voting, petitioning, and mobbing.

Kramer has pulled these arguments together, and in some places has extended them, in The People Themselves. His criticisms of the foundations of judicial review remain, but in more muted form. Whereas Kramer has, in the past, adamantly insisted that the Constitution's original understanding does not authorize judicial review, here he makes such comments much less frequently and only in passing, so much so that some readers may erroneously conclude that he has abandoned his earlier position. In toning down his claim, Kramer seems to have learned two lessons: first, that the argument against judicial review is a losing one (as we have argued, the Constitution's text contains numerous indications of judicial review's constitutionality and dozens of founders understood the Constitution to permit courts to review the constitutionality of federal statutes); and second, that the argument against judicial supremacy need not (and should not) rest on a futile assault on judicial review.

The other elements of Kramer's argument - the rejection of judicial supremacy and the celebration of popular constitutionalism remain pretty much as they were before. Though the arguments may be couched slightly differently and though Kramer exhumes more of the historical record, we do not believe that he has fundamentally altered his claims. For Kramer, the people themselves - not the courts - should decide the Constitution's meaning through the process of voting, petitioning, and mobbing.

We should disclose up front that we have criticized the various incarnations of Kramer's attacks on judicial review. ${ }^{4}$ As noted, we believe that the Constitution, properly understood, authorizes federal courts to judge the constitutionality of federal legislation. Even though the Constitution does not explicitly grant state courts the same power, such authority was unnecessary when the Constitution was enacted. ${ }^{5}$

4. See, e.g., Saikrishna B. Prakash \& John C. Yoo, The Origins of Judicial Review, 70 U. CHI. L. REV. 887 (2003) [hereinafter Prakash \& Yoo, Origins]; Saikrishna B. Prakash \& John C. Yoo, The Puzzling Persistence of Process-Based Federalism Theories, 79 TEX. L. REV. 1459 (2001); Saikrishna B. Prakash \& John C. Yoo, Questions for the Critics of Judicial Review, 72 GEo. WASH. L. REV. 354 (2003) [hereinafter Prakash \& Yoo, Questions]; John C. Yoo, The Judicial Safeguards of Federalism, 70 S. CAL. L. REV. 1311 (1997).

5. The Court has stated:

We begin with the axiom that, under our federal system, the States possess sovereignty concurrent with that of the Federal Government, subject only to limitations imposed by the Supremacy Clause. Under this system of dual sovereignty, we have consistently held that state courts have inherent authority, and are thus presumptively competent, to adjudicate claims arising under the laws of the United States.

Tafflin v. Levin, 493 U.S. 455, 458 (1989). 
Given background presumptions, because the Constitution never forbade state court review of the constitutionality of federal legislation, the state courts could engage in such review.

We share Kramer's view that the Constitution does not crown any branch supreme in the interpretation of the Constitution although we reach that conclusion based on the Constitution itself, not on exogenous theories of politics. We believe that each branch, in the course of exercising its powers, has an equal responsibility to interpret the Constitution and to act consistent with their own reading of it. Judicial review is merely the means by which federal judges implement the Constitution's higher authority in the course of deciding cases or controversies.

Nonetheless, we think that Kramer's arguments, even after his refinements and revisions, suffer from some significant flaws. To begin with, his book, like his previous works, never adequately defines what he means either by "judicial supremacy" or by "popular constitutionalism." One has some general sense, but Kramer never precisely spells out what he favors and what he opposes. Second, by focusing exclusively on history, Kramer misses the significant textual and structural arguments against the notion that the rest of government must obey the judiciary's constitutional interpretations.

By granting the "judicial power" to the federal courts, the Constitution gives the judiciary the authority to decide certain cases and controversies. The courts decide cases by issuing a final judgment. Once issued, the final judgment decides the case once and for all. Because the courts have the judicial power and jurisdiction over cases arising under the Constitution, when they issue final judgments in cases that involve constitutional interpretation, other branches must obey and enforce such judgments.

On the other hand, the judiciary's exercise of judicial power over cases arising under the Constitution does not suggest that the other branches (or anyone else for that matter) must embrace the constitutional interpretations that underlay any particular judgment. A judicial opinion does not command the same authority as a judgment and has no more authoritativeness, so far as the Constitution is concerned, than anyone else's opinion. ${ }^{6}$ Other branches can choose to look to judicial opinions in hopes of finding some judicial wisdom

6. Others have made a similar distinction between a judicial judgment and an opinion. See John Harrison, The Role of the Legislative and Executive Branches in Interpreting the Constitution, 73 CORNELl L. REV. 371 (1988); Gary Lawson \& Christopher Moore, The Executive Power of Constitutional Interpretation, 81 IOWA L. REV. 1267 (1996); Edward A. Hartnett, A Matter of Judgement, not a Matter of Opinion, 74 N.Y.U. L. REV. 123 (1999). One noted departmentalist has rejected such a distinction. See Michael Stokes Paulsen. The Most Dangerous Branch: Executive Power to Say What the Law Is, 83 GEO. L.J. 217 (1994). 
and to predict how future judges may decide a similar case, but they need not adopt the reasoning of judges.

Put another way, courts enjoy judgment supremacy - the other branches must enforce the judgments that resolve Article III cases or controversies. For the purpose of finally resolving a case, the judiciary decides who wins and loses, once and for all, even if everyone (save the prevailing party) thinks the courts have gotten it egregiously wrong. Courts lack interpretive supremacy - the power to resolve, once and for all, the Constitution's meaning. The Constitution nowhere requires that the other branches embrace the judiciary's constitutional readings. This was the argument Abraham Lincoln made in response to Dred Scott ${ }^{7}$ and we think Lincoln generally had it right. ${ }^{8}$ Even though the political branches must enforce the judiciary's judgments, absolutely no one need obey the judiciary's readings of the Constitution.

What about the people themselves? Though "We the People" established the Constitution and may amend it, the people themselves are not the arbiters of the Constitution's meaning. The Constitution does not establish a People's Court or a People's Committee by which the people definitively decide the Constitution's meaning. Moreover, we have never decided cases by reference to who won at the ballot box or by which side had the biggest, most violent mob. ${ }^{9}$

None of this denies the significant role that the people can play in constitutional interpretation. Individuals can voice their own readings of the Constitution. They can take actions, such as voting, petitioning, and assembling, which can shape what government actors believe and say about the Constitution. They can elect state and federal legislators who can trigger the process for amending the Constitution. They can elect a President and Senate who can use the appointments process to

\section{Dred Scott v. Sandford, 60 U.S. (19 How.) 393 (1856).}

8. Lincoln explained:

I do not forget the position assumed by some, that constitutional questions are to be decided by the Supreme Court; nor do I deny that such decisions must be binding in any case, upon the parties to a suit, as to the object of that suit, while they are also entitled to very high respect and consideration, in all parallel cases by all other departments of the government. And while it is obviously possible that such decision may be erroneous in any case, still the evil effect following it, being limited to that particular case, with the chance that it may be overruled and never become a precedent for other cases, can better be borne than could the evils of a different practice. At the same time the candid citizen must confess that if a policy of the government upon vital questions affecting the whole people, is to be irrevocably fixed by decisions of the Supreme Court, the instant they are made, in ordinary litigation between parties in personal actions, the people will have ceased, to be their own rulers, having, to that extent, practically resigned their government, into the hands of that eminent tribunal.

Abraham Lincoln, First Inaugural Address (Mar. 4, 1861), in 4 THE COLLECTED WORKS OF ABRAHAM LINCOLN 262, 268 (Roy P. Basler ed., 1953).

9. Some scholars argue national elections do occasionally function as quasiconstitutional amendments. For the theory of "constitutional moments," see BRUCE ACKerman, We the PEOPLE: Foundations (1993). 
change the composition of the federal courts and hence their direction. Yet there is no formal mechanism by which the people themselves can directly establish or fix the Constitution's meaning. While the people can be moved to take great actions in extraordinary situations, they are usually bystanders in the Constitution's day-to-day interpretation. The people themselves lack the time or the inclination to sit in review of every constitutional interpretation and somehow set it right.

Below, we first consider Kramer's arguments in favor of popular constitutionalism and against judicial supremacy. As noted, we regard them as lacking sufficient rigor, making it unclear what he favors and opposes. Then we advance the argument in favor of judgment supremacy and against interpretive supremacy.

I.

At the core of Kramer's book is a seemingly simple and "popular" proposition: the people themselves should decide the Constitution's meaning. ${ }^{10}$ Surprisingly though, Kramer never makes clear what this means. Does Kramer suppose that the people will routinely and finally decide constitutional questions? Or does he instead mean that, in extraordinary situations, the people will insist upon their preferred reading of the Constitution? Most of the time Kramer writes as if he favors the former, more active, popular role. ${ }^{11}$ Other times he seems to conclude that a more passive, rare popular constitutionalism is the best we can hope for from the busy, distracted, and typically divided people. $^{12}$ Kramer's discussion of popular constitutionalism is also muddled because by the end of his book, he seems to treat it synonymously with departmentalism - the idea that each coordinate

10. P. 227 ("Americans in the past always came to the same conclusion: that it was their right, and their responsibility, as republican citizens to say finally what the Constitution means. The question is, would Americans today do the same? Are we still prepared to insist on our prerogative to control the meaning of our Constitution?").

11. For example, Kramer states:

Neither the Founding generation nor their children nor their children's children, right on down to our grandparents' generation, were so passive about their role as republican citizens. They would not accept - did not accept - being told that a lawyerly elite had charge of the Constitution, and they would have been incredulous if told (as we are often told today) that the main reason to worry about who becomes president is that the winner will control judicial appointments.

P. 228

12. Kramer offers several options that do not directly involve American citizens at all.

The Constitution leaves room for countless political responses to an overly assertive Court: Justices can be impeached, the Court's budget can be slashed, the President can ignore its mandates, Congress can strip it of jurisdiction or shrink its size or pack it with new members or give it burdensome new responsibilities or revise its procedures.

P. 249 
branch of government must independently interpret the Constitution in the course of performing its own functions. ${ }^{13}$ Departmentalism, however, has no necessary relationship with popular constitutionalism.

\section{A. What Is Popular Constitutionalism?}

How should the people themselves decide the Constitution's meaning? Throughout most of his book, Kramer contends that the people will establish the Constitution's meaning by voting, petitioning, and, if need be, mobbing. Consistent with this view, Kramer celebrates episodes in English and American history where he claims the people insisted upon their understanding of fundamental law. In these episodes, the people themselves supposedly decided the meaning of fundamental law and judges had little or no role to play. Moreover, most of his book suggests that popular constitutionalism yields a viable, regular means of establishing a popular meaning. After all, Kramer's popular constitutionalism is meant to be a substitute for judicial supremacy, a mechanism that, whatever its faults, does regularly generate constitutional meaning.

At the end of his book, however, Kramer bows to reality, writing as if popular constitutionalism is possible in only those rare moments where the people become sufficiently angered or outraged. ${ }^{14}$ Here Kramer admits that we cannot expect the people themselves to establish the Constitution's meaning on a recurring, continuous basis. Hence, the choice at the end of the book is not between judicial supremacy and voting, petitioning, and mobbing. Rather, Kramer frames the choice as being between judicial supremacy and departmentalism. ${ }^{15}$ Given Kramer's persistent praise for popular constitutionalism, one supposes that he somehow believes popular constitutionalism and departmentalism are one and the same.

Yet Kramer's popular constitutionalism has no logical connection to departmentalism. Kramer's popular constitutionalism is a theory about the external relationship between the federal government and the polity; the people decide the Constitution's meaning for all three branches. Departmentalism is a theory about the internal relationship between the three branches of the federal government in interpreting

13. P. 252 ("It does not follow that nothing is at stake in the choice between a system of judicial supremacy and one based on departmental or coordinate construction.").

14. He explains that:

It takes a lot to persuade a majority in this country that particular rulings are wrong enough to overcome this presumption [of correctness].... The upshot is that the court's conduct must be quite provocative and very unpopular, usually over a sustained period, before it will produce actual legislative or executive countermeasure.

P. 252.

15. See supra note 13. 
the Constitution. Departmentalism, whatever its merits, cannot have grand populist pretensions, for it says absolutely nothing about the people's constitutional role. Departmentalism is more like "republican constitutionalism" than "popular constitutionalism."

To the extent Kramer makes an argument in favor of popular constitutionalism, he seems to claim that agency "slack" exists in the people's delegation of the power to interpret the Constitution: legislative, executive, and judicial officials may interpret the Constitution at odds with the people's preferences, were the people to undertake the task themselves. Indeed, during the ratification debates, many conceived of the relationship between the people and their elected representatives as one between a principal and its agents. ${ }^{16}$ But in focusing on agency slack, Kramer wholly ignores the benefits of delegation. The American people are not obsessed with the Constitution and its meaning. They clearly have higher priorities that occupy their time and energies (unbelievable as that might seem to constitutional law professors). Only when their agents interpret the Constitution outside the range of acceptable results will the people even consider taking popular action.

We see much wisdom in a departmentalist system where popular constitutionalism plays a role in extreme cases. Had Kramer described and defended it, there would be much worthy of praise. But Kramer never reconciles his powerful devotion to popular constitutionalism as a ready, effective means of establishing constitutional meaning with his eleventh-hour admission that the people cannot be counted upon to continuously and effectively challenge governmental interpretations. Nor does he discuss why he seems to believe that popular constitutionalism and departmentalism are identical. By the end of the book, though one is certain that Kramer favors popular constitutionalism, one has little idea what he means by it. ${ }^{17}$

\section{B. Is the Original Version of Popular Constitutionalism a Viable Means of Establishing the Constitution's Meaning?}

Kramer's original version of popular constitutionalism has an emphatically populist ring to it. He writes as if the "street" will decide what the Constitution means. We the People - the Constitution's

16. See THE Federalist No. 78 (Alexander Hamilton).

17. One could imagine a genuine, robust, popular constitutionalism: a plebiscitary system where constitutional questions are consistently and routinely put to the people. Because innumerable constitutional questions could arise, there would have to be some sorting mechanism to limit the issues that would be put to the people. Kramer never discusses such a system where the people could routinely and continuously decide the Constitution's meaning, probably because such a plebiscitary system has no basis in the federal Constitution. 
makers - would never allow anyone else to tell us what the Constitution means. None of the popular actions Kramer lauds, however, enables the people to regularly establish the Constitution's meaning. Voting, petitioning, and mobbing permit people to express their general preferences, but they do not enable the people to clearly express the fine distinctions often necessary in constitutional law.

Consider elections. As meaningful as elections are, we can never expect that they regularly will settle disputed questions of constitutional meaning. ${ }^{18}$ To begin with, popular voting is episodic. The election of federal officials every two, four, or six years cannot establish the meaning of complex constitutional provisions, such as the First and Second Amendments, for the votes are too infrequent to serve as a proxy on hundreds of contested constitutional law issues. Moreover, virtually all people cast their votes with nonconstitutional considerations in mind.$^{19}$ There are two reasons why nonconstitutional considerations regularly might take precedence. First, current voters might favor their own policy preferences over the preferences embodied in the Constitution. Second, even when constitutional meaning plays some role in a voter's choice, nonconstitutional considerations might still regularly trump, depending on the intensity of her preferences on the issues. A voter may favor a candidate because of his positions on taxes or the environment even if she disagrees with the candidate's views about the constitutionality of abortion or affirmative action. Finally, even the rare single-issue voter whose only criterion is fidelity to the Constitution faces a dilemma in expressing her preferences in a single vote. Few candidates will ever completely mirror a voter's constitutional preferences. Almost always, a voter will prefer Candidate $A$ on some issues of constitutional interpretation, but prefer Candidate $B$ on others. Election of a candidate may tell us about voters' preferences for the amalgamation of constitutional views held by that candidate, but they do not tell us much about voter preferences on the discrete constitutional issues in that bundle. For all these reasons, episodic voting for candidates is

18. Bruce Ackerman's theory of constitutional moments suffers from similar problems. See ACKERMAN, supra note 9. For a critique of the use of popular elections to establish constitutional meanings in the absence of changes to the text, see John C. Yoo, Laws as Treaties?: The Constitutionality of Congressional-Executive Agreements, 99 MICH. L. REV. 757, 779-88 (2001).

19. Exit polls taken during the 2004 presidential election revealed that moral values, the economy and jobs, terrorism, and the war in Iraq were most salient to voters. Also registering were: health care, taxes, and education. Proper interpretation of the Constitution, or even the more generous category of Supreme Court nominations, did not register highly. See Katharine Q. Seelye, Moral Values Cited as a Defining Issue of the Election, N.Y. TIMES, Nov. 4, 2004, at 4. 
an inexact means of determining the people's views about constitutional meaning. ${ }^{20}$

In theory, petitioning and mobbing do not present the same difficulties as voting. Were they so inclined, the people themselves could petition and/or mob to oppose or defend every official constitutional interpretation. Yet, several circumstances conspire to make such popular "interpretation" unlikely and ambiguous meaning that it typically will be impossible to discern a "popular" meaning for any given constitutional provision. First, we suspect that fewer individuals petition and mob as compared to those who vote. While many people believe voting is a civic duty, far fewer probably share this sense about petitioning and mobbing. Second, most questions of constitutional meaning do not arouse any level of popular emotion sufficient to trigger mobbing or petitioning. There are many more mundane constitutional matters than the hot button issues of abortion, privacy, and affirmative action. All this suggests that, for the vast majority of constitutional questions, the people will not take to the streets.

Even where some issue moves a large number of people on an issue that involves the Constitution, the meaning of popular action will be indeterminate. Suppose one million people conduct a mass protest and letter writing campaign against the death penalty. Does it follow that they have established a popular meaning of the Eighth Amendment's cruel and unusual punishment prohibition? How do we construe the silence of the millions who might agree with the judiciary's conclusions about the constitutionality of the death penalty, and so choose to do nothing? Or suppose pro-life groups succeed in gathering protest marches that dwarf the size of pro-choice rallies. Does this mean that the pro-life group "wins" the interpretational question? Even if we agreed that the overwhelming majority of the people agreed with a reading of the Constitution, the precise meaning would be indeterminate without a text. For instance, we know prochoice rallies support Roe $v$. Wade, ${ }^{21}$ but are rally goers uniformly against parental notification and in favor of permitting late-term abortions? We can guess, but these and other meanings are hardly obvious. Given the obvious difficulties with discerning a popular

20. In contrast, because they "vote" much more often, members of the three branches of government face few impediments to acting upon their understanding of the Constitution. Judges may issue judgments precisely on a statute's constitutionality; when presented with legislation, executives may (indeed must) judge the constitutionality and the wisdom of it; and legislators, since they vote on each bill, are afforded a ready opportunity to gauge that bill's constitutionality. While each of these officials may choose to ignore questions about the constitutionality of government action, they at least have a much easier time of interpreting the Constitution. The people are not so fortunate.

21. 410 U.S. 113 (1973). 
constitutional interpretation and given that Kramer never presents a theory explaining why a mob or petition should be considered proxy for the people as a whole, we do not know why Kramer places such stock in voting, petitioning, and mobbing.

If all this is true, what of Kramer's claim that many founding-era politicians cited the people as the Constitution's ultimate guardians? Were people more virtuous, civic-minded, and politically active in the good old days? We agree that many founders who cited the availability of judicial review as a means of checking Congress also emphasized the role the people might play if Congress violated the Constitution. While some of this was perhaps sincere, much of it was an attempt to respond to claims that the Constitution granted too much power to the federal government. After citing the Constitution's structural protections, such as bicameralism, the presidential veto, and judicial review, the Constitution's supporters cited the people as the Constitution's ultimate defenders.

Yet few Federalists seriously could have expected that the people would consistently serve as dependable, regular, and faithful guardians of the Constitution. After all, the people themselves had pressed state legislators to violate the state constitutions, so much so that the judiciaries came to be seen as necessary bulwarks of limited government and of minority rights. ${ }^{22}$ Moreover, as James Iredell wrote at the time, the people would suffer quite a few constitutional violations before they could be expected to rise up. ${ }^{23}$ People have neither the time nor the inclination to examine the wisdom and constitutionality of every governmental action. It is not that government officials are superior diviners of the Constitution's meaning; it is that the people, after they toil, pray, and spend time with their families, have precious little time to serve as the ever-watchful guardians of the Constitution.

\section{The Perils of Popular Constitutionalism}

Though Kramer never systematically considers the potential drawbacks of popular constitutionalism, he does admit that it suffers a few weaknesses. In his Epilogue, he writes that it "takes a lot to persuade a majority in this country that particular rulings are wrong enough to overcome" the modern-day presumption that the judiciary has properly construed the Constitution (p. 252). Kramer also admits

22. See JACK N. Rakove, ORIginal MeaningS 49-50 (1996).

23. As Iredell explained, "We well know how difficult it is to excite the resistance of a whole people.... A thousand injuries may be suffered, and many hundreds ruined, before this can be brought about." AN ELECTOR, TO THE PUBLIC, IN 2 LIFE AND CORRESPONDENCE OF JAMES IREDELL 145, 147 (Griffith J. McRee ed., Peter Smith 1949) (1857). 
that "[t]he upshot is that the Court's conduct must be quite provocative and very unpopular, usually over a sustained period, before it will produce actual legislative or executive countermeasures" (p. 252). These concessions rob popular constitutionalism of much of its attractiveness.

But popular constitutionalism has many other difficulties. First, there may be reason to doubt whether the people are sufficiently familiar with the Constitution to discern its meaning (even assuming that we have agreed upon some way of establishing its meaning). Second, it seems likely that many people pay less attention to interpreting the Constitution and more to their policy preferences. Third, Kramer is never clear what the Constitution actually represents. Is it merely the preferences of the current majority for certain rules of self-government, in which case it should be easy for the people to change them? Or does the Constitution establish enduring rules set out by previous generations that are intended to be difficult to change? Although Kramer often refers to the people's ability to settle the Constitution's meaning, at times his ardor for popular constitutionalism seems to stem frcm the notion that popular interpretation of the Constitution allows the people to alter it. ${ }^{24}$

The questions that necessarily arise from Kramer's academic project are intricate and difficult. We do not pretend to know the answer to all these questions. But some discussion of each of them (and many others) would have been appropriate in a book extolling the people themselves as final constitutional interpreters. Unfortunately, Kramer's book is short on the specifics of popular constitutionalism.

Once again, we are not opposed to the idea that the Constitution contemplates an extraconstitutional check on the branches of the federal government. But we see many problems with the idea of the people as the constant and final interpreters of the Constitution. And as we discuss in the next parts of this essay, whether the people interpret the Constitution or not does not meaningfully bear on how the federal government itself allocates the function of constitutional interpretation.

II.

The second core feature of The People Themselves is its criticism of judicial supremacy. Kramer, however, never identifies his precise

24. This is certainly the worry in removing the power of interpretation from the judiciary's hands. See City of Boerne v. Flores, 521 U.S. 507, 529 (1997) ("Shifting legislative majorities could change the Constitution and effectively circumvent the difficult and detailed amendment process contained in Article V."). 
target. Does Kramer merely oppose interpretive supremacy - the view that the courts are the final arbiters of the Constitution's meaning, such that the rest of society (including the political branches) must embrace its understandings? Or does he also oppose the more limited notion of judgment supremacy - that even if the courts are not supreme in their constitutional expositions, the other branches must nonetheless enforce their judgments? The People Themselves seems oblivious to the many scholars who have wrestled with these issues before; discussion of their arguments would have made these questions clear. Here, we define judicial supremacy - something Kramer does not do - and criticize his arguments against it.

\section{A. What Is Judicial Supremacy?}

"Judicial Supremacy" is a well-worn phrase that bears several meanings. One is that the judiciary determines the Constitution's meaning such that the entire nation must accept the judiciary's reading of the Constitution. This seems to be the judicial supremacy that finds voice in Cooper v. Aaron..$^{25}$ Once the Supreme Court concluded that the Constitution prohibited segregated schools, all federal and state officials had to take measures to end segregation in schools or otherwise violate their oath to the Constitution. Under this extreme version of judicial supremacy, it is not only emphatically the judiciary's duty to say what the Constitution means, but it is also the exclusive right of the judiciary to say what the Constitution means. ${ }^{26} \mathrm{We}$ call this view "interpretive supremacy."

Another form of judicial supremacy is "judgment supremacy," where the only thing that is supreme is the judiciary's judgments. On this view, the executive branch and Congress need not adopt the judiciary's conclusions about the Constitution's meaning. The political branches are free to articulate, advocate, and act upon alternative constitutional understandings. The only thing the political branches cannot do is ignore or thwart the final judgments issued by courts. Hence, members of Congress may pass legislation contrary to the judiciary's constitutional interpretations so long as they do not impede or overturn a particular judgment. Likewise, the President may vigorously and publicly disagree with the Supreme Court's

25. 358 U.S. 1, 18 (1958). As the Court explains:

It follows that the interpretation of the Fourteenth Amendment enunciated by this Court in the Brown case is the supreme law of the land, and Art. VI of the Constitution makes it of binding effect on the States any[t]hing in the Constitution or Laws of any State to the Contrary notwithstanding.

Id. (internal quotation marks omitted).

26. Marbury v. Madison, 5 U.S. (1 Cranch) 137, 177 (1803) ("It is emphatically the province and duty of the judicial department to say what the law is."). 
interpretation of some constitutional provision so long as she continues to execute the judiciary's judgments.

An important but rarely discussed exception to judgment supremacy helps prove the rule. The pardon power grants the President the power to nullify judgments against those convicted of committing offenses against the United States. ${ }^{27}$ One could argue that the Constitution recognizes only this one exception to the federal courts' final say over cases, implying that neither the President nor Congress enjoy the ability to ignore judgments in any other area.

While Kramer obviously opposes interpretive supremacy for the judiciary, he never clearly states his position on judgment supremacy. He says little about what the political branches must do when faced with a judgment based on reasoning they reject. This is odd because he is clearly aware of the distinction. Indeed, he cites James Madison as opposing judgment supremacy because Madison apparently believed that judgment supremacy (being the last in time to decide a constitutional question) practically guaranteed interpretive supremacy (p. 252).

At times, Kramer hints that his rejection of judicial supremacy encompasses both interpretive and judgment supremacy. For instance, Kramer states that under the departmentalist theory, the judiciary's decisions only have force if the other branches adopt them. ${ }^{28}$ Even though there is an ambiguity in this claim (because one does not know if Kramer is referring to the opinion, the judgment, or both), this discussion seems to suggest that Kramer opposes both interpretive and judgment supremacy. Another time, however, Kramer uses "judicial supremacy" in a way that suggests that he does not mean for it to refer to judgment supremacy. Discussing Lincoln, Kramer claims that Lincoln opposed judicial supremacy. ${ }^{29}$ Yet as we have noted, Lincoln generally believed he had to enforce judgments. Kramer's treatment of Lincoln suggests that whenever Kramer refers to judicial supremacy, he only means interpretive supremacy and not judgment supremacy. After reading his book, we could not discern Kramer's position on judgment supremacy.

27. U.S. CONST. art. II, $\S 2$, cl. 1.

28. P. 252 (contrasting judicial supremacy with departmentalism and suggesting that only under the latter theory does the authority of judicial decisions depend upon the reactions of other branches); see also p. 235.

29. P. 212 (describing Lincoln's efforts to recognize black citizenship in a number of contexts). 


\section{B. Kramer's Surprisingly Weak Case Against Judicial Supremacy}

Regardless of the version of judicial supremacy under consideration, it is certainly the regnant ideology in the modern academy. Kramer clearly recognizes that popular constitutionalism, whatever its historical support, enjoys little to no popular or scholarly backing. ${ }^{30}$ Knowing this, Kramer ought to systematically have explained the benefits and drawbacks of each, with an eye to explaining why popular constitutionalism is functionally superior to judicial supremacy.

Yet Kramer never does this. He takes a few stabs against judicial supremacy, arguing against the notion that it is necessary to avoid conflicts about the meaning of the law and against the notion that courts offer a superior means of protecting the Constitution's fundamental commitments. He makes no similar effort to explore the comparative costs and benefits of popular constitutionalism.

Rather than mounting a comprehensive attack on judicial supremacy, Kramer's book compiles vast amounts of history to show that, from time to time, members of the political branches and/or the public have opposed judicial supremacy. While his historical claims are interesting, he never explains why we should care about this history. Is it because the original understanding of the Constitution binds us today? ${ }^{31}$ Is it because history is the product of a tradition that should be followed as precedent in a system of common law constitutionalism? Is history simply the record of previous decisions that should be followed only when appropriate? Rather than make any of these claims, Kramer's argument appears to be that since many people have opposed judicial supremacy in the past and since many of them claimed that the people were the Constitution's ultimate guardians, this is how we ought to read the Constitution today.

Of course, such arguments will not convince supporters of judicial supremacy to embrace popular constitutionalism. Those who favor judicial supremacy usually see wisdom in having one institution decide the Constitution's final meaning. ${ }^{32}$ Having an ultimate arbiter of the Constitution's meaning serves the values of finality and stability in the law. While supporters of judicial supremacy might conceivably favor legislative supremacy or executive supremacy, they will not abandon

30. P. 8 ("Many, perhaps most, scholars today believe that 'popular sovereignty' is and can be expressed only at rare moments, that 'the people' are otherwise either absent or present only as an abstraction.").

31. In his earlier work Kramer expressly denies that we ought to embrace popular constitutionalism (and thereby reject judicial supremacy) merely because the Founders made this choice. Kramer, We the Court, supra note 3 , at 14.

32. See, e.g., Larry Alexander \& Frederick Schauer, On Extrajudicial Constitutional Interpretation, 110 HARV. L. REV. 1359, 1387 (1997) (defending judicial supremacy). 
judicial supremacy for a system long on populist rhetoric and short on specifics.

Others support judicial supremacy because they clearly prefer the judiciary's constitutional readings in certain substantive areas over the readings that would prevail in the absence of judicial supremacy. Had their preferences prevailed through the regular majoritarian process, they likely would not have supported judicial supremacy in the first place. Hence the last thing these folks would want is a system of constitutional interpretation by majority vote.

Despite having read Kramer's books and articles, we have only a vague sense of what popular constitutionalism is and why Kramer favors it. We also have an inadequate sense of what Kramer means by judicial supremacy and why Kramer opposes it. We think these difficulties stem from Kramer's preoccupation with history. As originalists, we love history; but even we see the wisdom of a little more precision and analysis of that history, including an explanation for why history matters. In the end, The People Themselves reads more like a two-century long story than an argument for a greater popular role in constitutional interpretation.

\section{III.}

While we are critical of Kramer's claims, we could hardly blame him for attempting to resolve the central question that has fascinated many constitutional law scholars. A number of leading scholars recently have questioned the legitimacy, usefulness, or existence of judicial review, including Michael Klarman, ${ }^{33}$ Richard Posner, ${ }^{34}$ Mark Tushnet, ${ }^{35}$ Adrian Vermeule, ${ }^{36}$ and Jeremy Waldron. ${ }^{37}$ A broader group of authors, including Larry Alexander and Frederick Schauer, ${ }^{38}$ Neal Devins and Louis Fisher, ${ }^{39}$ Sanford Levinson, ${ }^{40}$ Michael McConnell, ${ }^{41}$ Robert Nagel, ${ }^{42}$ and Michael Stokes Paulsen, ${ }^{43}$ among

33. Michael J. Klarman, What's So Great About Constitutionalism?, 93 NW. U. L. REV. 145 (1998).

34. RICHARD A. POSNER, FRONTIERS OF LEGAL THEORY 15-27 (2001).

35. MARK TUSHNET, TAKING THE CONSTITUTION AWAY FROM THE COURTS (1999).

36. Adrian Vermeule, Judicial Review and Institutional Choice, 43 WM. \& MARY L. REV. 1557 (2001).

37. JEREMY WALDRON, LAW AND DISAGREEMENT (1999).

38. Alexander \& Schauer, supra note 32.

39. Neal Devins \& Louis Fisher, Judicial Exclusivity and Political Instability, 84 VA. L. REV. 83 (1998).

40. Sanford Levinson, Could Meese Be Right This Time?, 61 TUL. L. REV. 1071 (1987).

41. Michael W. McConnell, Institutions and Interpretation: A Critique of City of Boerne v. Flores, 111 HARV. L. REV. 153 (1997). 
others, has been debating whether the federal judiciary enjoys interpretive supremacy. Along with Kramer's book, much of this discussion seems to have been precipitated by the Rehnquist Court's federalism decisions and by its declaration in City of Boerne v. Flores ${ }^{44}$ that its interpretation of the Fourteenth Amendment binds Congress. We have yet to see whether academics display the same level of concern about judicial supremacy in the wake of the Supreme Court's unprecedented declaration of authority to review the legal status of enemy prisoners captured in wartime. ${ }^{45}$ Nonetheless, these articles draw on a deeper trend of skepticism toward judicial review inspired by Cooper v. Aaron ${ }^{46}$ and the decisions of the Warren Court in the 1960s, or by the decisions of the Four Horsemen in the New Deal period. In this respect, these authors are tackling the same problems that were central to the work of Jesse Choper, ${ }^{47}$ John Hart Ely, ${ }^{48}$ Learned Hand, ${ }^{49}$ and Herbert Wechsler. ${ }^{50}$

It would be unfair to criticize Kramer without at least sketching out our own views on the subject. After all, to quote our teacher Akhil Amar, it takes a theory to beat a theory. ${ }^{51}$ In our prior work, we argued that the Constitution contemplates and authorizes judicial review. ${ }^{52}$ The Constitution assumes that each branch will interpret the Constitution and act in a manner consistent with it. The judiciary is. not excepted from that fundamental obligation. When a judge hears a case involving a conflict between some statute and the Constitution, the judge must favor the Constitution.

Here we argue in favor of judgment supremacy, but against interpretive supremacy. We propose that the only obligation the other branches have to judicial decisions interpreting the Constitution is to enforce the judgment in that individual case. They have no obligation

42. Robert F. Nagel, Judicial Supremacy and the Settlement Function, 39 WM. \& MARY L. REV. 849 (1998).

43. Paulsen, supra note 6.

44. 521 U.S. 507, 536 (1997).

45. See Rasul v. Bush, 124 S. Ct. 2686 (2004); Hamdi v. Rumsfeld, 124 S. Ct. 2633 (2004).

46. 358 U.S. 1 (1958). (1980).

47. Jesse H. Choper, Judicial Review and the National Political Process

48. JOHN HART ELY, DEMOCRACY AND DISTRUST (1980).

49. LEARNED HAND, THE Bill OF Rights (1958).

50. Herbert Wechsler, The Political Safeguards of Federalism: The Role of the States in the Composition and Selection of the National Government, 54 COLUM. L. REV. 543 (1954).

51. See also Richard A. Epstein, Common Law, Labor Law, and Reality: A Reioinder to Professors Getman and Kohler, 92 YALE L.J. 1435, 1435 (1983) ("Nonetheless it takes a theory to beat a theory....").

52. See, e.g., Prakash \& Yoo, Origins, supra note 4; Prakash \& Yoo, Questions, supra note 3 . 
to adopt and implement the constitutional interpretations that form the basis of those judgments. This was the position President Abraham Lincoln took toward Dred Scott. ${ }^{53}$ We also discuss how the political branches should respond to judicial efforts to secure interpretive supremacy for judicial decisions.

Before beginning, we should make our aims and methodology clear. Our aims are positive and not normative. Here, we only address what the Constitution originally meant. Nonetheless, though our argument is a positive one, we believe that our rendition of the Constitution's implicit interpretational rules is normatively attractive. Our methodology in discerning the Constitution's meaning is originalist: we merely try to establish what the Constitution meant when it was ratified. We do not think that political developments subsequent to the Constitution's ratification should control this reading, although they do provide data on how certain systems have worked out in practice.

We start off with what we hope is common ground: that the Constitution permits, indeed requires, each branch of government to interpret the Constitution. Some, such as Kramer, have argued that the Constitution does not expressly authorize judicial review and that the other branches somehow have a greater claim to interpret the Constitution. This gets things exactly backward. From the beginning, the judiciary's power to interpret the Constitution has been on firm ground and it was sometimes (but incorrectly) claimed that the other branches have no place in interpreting the Constitution. The judicial power to hear cases arising under the Constitution was understood to be the authority to decide the meaning of the Constitution in such cases. This is one aspect of the Constitution's supremacy as higher law superior to a statute. If a case presents a conflict between a constitutional provision and a statute, a federal court exercises judicial review in choosing the proper rule of decision.

Several constitutional provisions confirm this intuition. Article VI requires that the "Constitution, and the Laws of the United States which shall be made in Pursuance thereof; and all Treaties made, or which shall be made, under the Authority of the United States, shall be the supreme Law of the Land ... any Thing in the Constitution or Laws of any State to the Contrary notwithstanding." 54 Again, in order to decide whether a state law conflicts with a federal constitutional provision, federal courts would have to interpret the federal constitution first. The Supremacy Clause also makes clear that the Constitution itself is law to be enforced in court, rather than a vague

53. See supra note 8.

54. U.S. CONST. art. VI, cl. 2. 
set of political-legal principles outside of judicial cognizance. Both Article III and Article VI include the Constitution as a source of law the courts will enforce in performing their unique constitutional duty to decide cases or controversies.

While the other branches lack such specific interpretational authority, they too must interpret the Constitution. After all, members of each branch take an oath to the Constitution, which means, at a minimum, that they must discern the meaning of the Constitution they are pledged to uphold.$^{55}$ What makes them different is the form that their review takes. The President, for example, has the duty to "preserve, protect and defend the Constitution." 56 To defend the Constitution, the President presumably must have some idea of what it means. Moreover, to exercise his own constitutional powers properly, the President must interpret them first. To take but one example, the President must give meaning to different constitutional provisions when deciding whether to veto a law that might be unconstitutional. This is not judicial review because it does not arise in the course of deciding a case or controversy. Nevertheless, this presidential review occurs through the President's performance of his unique constitutional responsibilities.

A similar analysis applies to Congress. Per the oaths clause, congressmen must support the Constitution. Consistent with their duty to support the Constitution, congressmen cannot enact laws that are unconstitutional. Individual members of Congress, therefore, have the independent duty to review the constitutionality of proposed legislation before them and to oppose unconstitutional laws. The same principle is true for state executive, legislative, and judicial officials: each must interpret the Constitution in the course of performing their own constitutional responsibilities.

Given all this, judicial review is not unique. It is merely the means by which the federal judges obey the Constitution while executing their constitutional function of deciding cases or controversies. Other branches of the government have the same obligation, but different functions that give it expression. As President Andrew Jackson observed when vetoing legislation rechartering the Bank of the United States:

55. We understand that a constitution might enshrine one institution as the final arbiter of a constitution's meaning, in which case all others must adhere to that institution's readings of the constitution. But even if a constitution contained such a provision, one would still have to interpret the constitution to see if it contained the interpretive supremacy provision described above. Some level of independent interpretation is simply unavoidable. We, of course, do not believe that the federal Constitution contains any provision relating to
interpretive supremacy.

56. U.S. CONST. art. II, § 1, cl. 8. 
It is as much the duty of the House of Representatives, of the Senate, and of the President to decide upon the constitutionality of any bill or resolution which may be presented to them for passage or approval as it is of the supreme judges when it may be brought before them for judicial decision. ${ }^{57}$

Judicial review is just a subset of a more general category of constitutional review.

Where are the people in this structure? Obviously, the people are free to interpret the Constitution as they see fit. They need not look to the legislative, executive, or judiciary for guidance in discerning the Constitution's meaning any more than these branches must look to each other. As noted earlier, however, the people are not uniquely invested with the power to establish the Constitution's meaning. The Constitution does not contemplate that the people will regularly, routinely establish its meaning on a government-wide scale to the exclusion of other governmental actors.

To the extent that the founders believed that the people could institutionally exercise the power to interpret the Constitution, they appear to have thought of it on a smaller, more manageable scale. Historians have shown that framing-period thought allowed juries to interpret the Constitution when deciding cases. ${ }^{58}$ No single jury, however, can bind another to its constitutional interpretation. Nor can it force the government to act positively to carry out its views. Nor can its views extend beyond criminal law. Juries can only prevent the government from enforcing a certain constitutional meaning through an individual criminal prosecution. Other than through juries, the Constitution permits popular interpretation of its terms only through Article V's amendment process.

More realistically, the Constitution envisions that the people will make their legal views known, in a very rough and imprecise way, through the political process. This process is endogenous to the Constitution, because it is established by the Constitution itself. The electorate can vote for candidates who come closest to mirroring their desired constitutional views; presidents can then nominate, and the Senate confirm, federal judges who share those views. The people also can elect state officials that come close to the people's desired constitutional views, and these officials can attempt to use the states' place in our political system to influence the actions of the federal

57. Andrew Jackson, Veto Message (July 10, 1832), in 2 A COMPILATION OF THE MESSAGES AND PAPERS OF THE PRESIDENTS 1789-1897, at 576, 582 (James D. Richardson ed., Washington, Government Printing Office 1896).

58. Shannon C. Stimson, The american Revolution in the law: AngloAMERICAN JURISPRUDENCE BEFORE JOHN MARSHALL (1990); Akhil Reed Amar, The Bill of Rights as a Constitution, 100 YALE L.J. 1131 (1991). 
government. This is, after all, what Jefferson and Madison attempted in the Virginia and Kentucky Resolves. ${ }^{59}$ Kramer is right to point out that voting, petitioning, and other forms of mass political activity give the people a role in constitutional interpretation. But this role is indirect.

Kramer, however, made two mistakes on this issue. First, he believes that since it was possible for the people to influence the interpretation of the Constitution, the people must enjoy interpretive supremacy to the point of precluding judicial review. But that makes no sense, just as the argument that because the people can interpret the Constitution through the jury there is no need for judicial review does not make sense. Jesse Choper ${ }^{60}$ and Herbert Wechsler ${ }^{61}$ made a similar mistake in suggesting that judicial review of federalism questions was unnecessary because states had a strong hand in the composition of the federal government. ${ }^{62}$ The one power does not necessarily exclude the other.

Second, Kramer has confused exogenous and endogenous means for interpreting the Constitution. The Constitution's endogenous mechanism for popular participation in interpretation is the electoral process. An exogenous method originates outside the Constitution itself - massive political action, refusal to follow the Constitution (or a current interpretation), or opposition to the government - and cannot be defined or limited by reference to the Constitution. In certain extreme and unusual cases, the people can take such exogenous measures, but by doing so, they reject the existing legal framework. Hence, the people of the states adopted the Constitution by a process that violated the rules for amending the Articles of Confederation. ${ }^{63}$ One can view the Civil War as an attempt by a minority of the American people to engage in popular mobilization to change (or maintain) a constitutional meaning at odds with that to be adopted by the elected branches of government. But because these

59. The Kentucky Resolves were adopted on November 10, 1798, and November 14 , 1799. See 5 THE Founders' CONSTITUTION 131-35 (Phillip B. Kurland \& Ralph Lerner eds., 1987). The Virginia Resolves were adopted on Dec. 21, 1798. See id. at 135-36; see also Akhil Reed Amar, Kentucky and the Constitution: Lessons from the 1790s for the 1990s, 85
KY. L.J. 1 (1997).

60. See CHOPER, supra note 47.

61. See Wechsler, supra note 50.

62. Professor Kramer has made this mistake in previous pieces. See Prakash \& Yoo, Questions, supra note 4, at 355 ("Professor Kramer, like Professors Jesse Choper and Herbert Wechsler before him, ignores the constitutional text and structure. Fairly read, the Constitution's text and structure establishes judicial review in a number of ways.") (internal footnotes omitted).

63. ARTICLES OF CONFEDERATION art. XIII (U.S. 1781) ("[N]or shall any alteration at any time hereafter be made in any of them; unless such alteration be agreed to in a congress of the united states, and be afterwards confirmed by the legislatures of every state."). 
measures are exogenous to the Constitution, they do not, as a formal matter, alter the Constitution's separation of powers or its system of decentralized constitutional interpretation.

History suggests that these exogenous efforts to alter the Constitution's meaning may not be as durable as the old-fashioned path of amending the Constitution. Kramer does not differ much from Bruce Ackerman in the view that mass political movements exogenous to the Constitution should affect its interpretation. ${ }^{64}$ Both treat the New Deal, with its overwhelming majorities in support of the expansion of federal power, the creation of the administrative state, and the taming of the Supreme Court, as a legitimate change to the interpretation of the Constitution. There is an important difference, however, between the New Deal and earlier periods. During Reconstruction, for example, the radical Republicans enshrined their constitutional understanding in three constitutional amendments that significantly altered the relationship between the federal government, the states, and citizens. In contrast, the New Deal period experienced no constitutional amendments. This may explain why certain elements of the New Deal state have undergone criticism and efforts at change. ${ }^{65}$

Our departmentalist approach to constitutional review by the three branches clearly rejects the notion of interpretive supremacy. Courts are not supreme in interpreting the Constitution. No branch is. The constitutional text and structure merely permit the federal courts a power of judicial review in the same way that they should be understood to grant the other branches the power of interpreting the Constitution while performing their own duties. Indeed, the authority of the federal courts, by design, is far weaker than that of the other branches. While the judiciary enjoys sufficient independence - due to life tenure and irreducible salary - to check the other branches without fear of direct reprisal, it has no institutional mechanisms to actually enforce its constitutional views. Enforcement of the Supreme Court's decisions, as many have noted since the time of Alexander Hamilton, ${ }^{66}$ ultimately depends on the agreement of the other branches and the support of the public.

64. See ACKERMAN, supra note 9.

65. See, e.g., United States v. Lopez, 514 U.S. 549, 596 (1995) (Thomas, J., concurring) ("I am aware of no cases prior to the New Deal that characterized the power flowing from the Commerce Clause as sweepingly as does our substantial effects test. My review of the case law indicates that the substantial effects test is but an innovation of the 20th century.").

66. The judiciary has, as Hamilton explained, "no influence over either the sword or the purse, no direction either of the strength or of the wealth of the society, and can take no active resolution whatever. It may truly be said to have neither Force nor Will, but merely judgment ...." Even to enforce its judgments, he observed, the judiciary "must ultimately 
At times, the scholarly obsession with judicial review and the counter-majoritarian difficulty exaggerates the power of the courts. As an institution, the federal courts have relatively few personnel and only about $\$ 3$ billion in annual funds. Sitting at the top of a slow, decentralized decisionmaking process, the Supreme Court hears roughly eighty cases a year. These limited resources restrict the ability of the federal courts to hear cases of all kinds, not just constitutional cases. Federal courts depend on private parties to bring constitutional issues to them, and they raise numerous procedural barriers - such as standing, ripeness, mootness, the political question doctrine, and the avoidance doctrine - to the decision of those issues. Because of their greater responsibilities and scope for action, the other branches will encounter constitutional issues more often and have greater resources to reach decisions and enforce them. Not only does Congress enact many more laws than the Supreme Court can review, but because Congress often delegates rulemaking authority to the agencies, administrative regulations produce a large number of laws every year that the courts cannot possibly review.

As departmentalists in the Jeffersonian and Lincoln tradition, we accept that each branch may make final decisions within their spheres of responsibilities based on their own readings of the Constitution. Few doubt that the President may veto a bill that he believes to be unconstitutional, refuse to prosecute under a criminal law he believes to be unconstitutional, or pardon those previously convicted under a law he concludes is unconstitutional. But what happens when the branches adopt conflicting interpretations of the Constitution? In the academic literature, the focal point for this question has been whether the President must enforce Supreme Court decisions with which he disagrees. Presidents themselves have held varying views on this question. President Eisenhower, for example, enforced Brown $v$. Board of Education ${ }^{67}$ even though he reportedly was skeptical about the decision on the merits. ${ }^{68}$ President Andrew Jackson famously refused to enforce a Marshall Court order stopping the removal of Indian tribes from Georgia by exclaiming: "John Marshall has made his decision, now let him enforce it."69 Abraham Lincoln took something of a middle view by concluding that he was not bound by

depend upon the aid of the executive arm." THE FEDERALIST No. 78, at 523 (Alexander Hamilton) (Jacob E. Cooke ed., 1961).

67. 347 U.S. 483 (1954).

68. Lucas A. Powe, Jr., The Warren Court and american Politics 35-36, 157 59 (2000).

69. DAVID C. TOTH, CHIEF JUSTICE MARSHALl AND THE GROWTH OF THE AMERICAN RePublic 365 (1948); G. Edward White, THE MARshall Court and Cultural CHANGE, 1813-35 (1988). 
the Court's reasoning in Dred $S$ cott ${ }^{70}$ which had struck down a congressional effort to limit slavery in the territories, but had an obligation to enforce the judgment upon the parties in the case itself. As Lincoln said in his debates with Stephen Douglas:

We do not propose that when Dred Scott has been decided to be a slave by the court, we, as a mob, will decide him to be free.... [B]ut we nevertheless do oppose that decision as a political rule which shall be binding on the voter, to vote for nobody who thinks it wrong, which shall be binding on the members of Congress or the President to favor no measure that does not actually concur with the principles of that decision. ${ }^{71}$

In terms of academic views, it is probably fair to say that the majority of scholars support judicial supremacy: the Court enjoys interpretive supremacy such that its decisions bind the other branches not just in the case before it but all other similar cases. ${ }^{72}$ Professor Laurence Tribe speaks for most when he writes that "the Executive Branch must enforce the law according to the Executive's view of what the Constitution requires... so long as the Executive does not thereby usurp the role of the Article III Judiciary as the ultimate expositor of the Constitution in actual cases and controversies." 73 On the other end of the spectrum, Professor Michael Paulsen has adopted the Jacksonian position, rejecting both judgment supremacy and interpretive supremacy. ${ }^{74}$

The Lincoln position has failed to attract many defenders, in part perhaps because it has proven difficult to explain why a President should be able to simultaneously disagree with the Court's interpretation of the Constitution, yet nonetheless remain under obligation to enforce the judgment. No doubt Lincoln himself was forced to reach this compromise by the need to appeal to Republican antipathy toward slavery without taking the radical political position of disregarding the Supreme Court entirely. ${ }^{75}$ Nonetheless, we think that Lincoln had matters just about right. Each branch, as a practical matter, must interpret the Constitution when performing its unique functions, and the Constitution does not set up one branch's decision on these issues above any other. Therefore, Lincoln was right to say

70. Dred Scott v. Sandford, 60 U.S. (19 How.) 393 (1856).

71. Abraham Lincoln, Sixth Debate with Stephen A. Douglas (Oct. 13, 1858), in 3 COLLECTED WORKS OF ABRAHAM LINCOLN, supra note 8, at 245, 255.

72. See, e.g., 1 LAURENCE H. TRIBE, AMERICAN CONSTITUTIONAL LAW 726 (3d ed. 2000); Daniel A. Farber, The Supreme Court and the Rule of Law: Cooper v. Aaron Revisited, 1982 U. ILL. L. REV. 387.

73. TRIBE, supra note 72 , at 726.

74. Paulsen, supra note 6, at 226.

75. DAVID Herbert DONALD, LINCOLN 199-202 (1995). 
that the reasoning of Dred Scott did not bind his views or policies, as President, on the restriction of slavery in the territories. We also think, however, that Lincoln was right to conclude that executives had a responsibility to enforce the judgment in Dred Scott itself and return Dred Scott to his owner (even though we stress that we obviously disagree strongly with Chief Justice Taney's reading of the Constitution).

Why? We believe this conclusion arises from the principle that the Constitution makes each branch supreme in performing its respective functions. The courts are supreme in resolving cases. We can criticize their judgments, but they are final and to be enforced because the Constitution commits the resolution of certain disputes to the courts. This point may become clearer when we examine the difference between a judgment and an opinion. The judgment is the necessary and legally operative action of the federal courts, and as such it is the only part of a decision which has constitutional force. It is the result of the judiciary's power to decide cases or controversies. The opinion is the court's explanation of why it reached that particular judgment. It is only an explanation for a judgment. Suppose federal courts only issued judgments and not opinions. The other branches would still have a constitutional duty to implement those judgments as the final exercise of a coordinate branch's constitutional authority. Scholarly focus on the opinion has clouded our understanding that only the judgment represents the court's final action.

As we noted, other branches also have this kind of operational supremacy. An obvious example is the President's pardon power. A president may pardon someone on a wholly idiosyncratic and misguided understanding of the Constitution. Along with the official document of the pardon, the President might issue his opinion as to why the pardon was necessary to right an unconstitutional wrong. That opinion might directly conflict with the judiciary's interpretation of the same constitutional provision. Nonetheless the pardon is final and the judiciary cannot ignore it on the grounds that the President's constitutional reasoning is erroneous. For instance, suppose that the President interprets the Constitution as forbidding the prosecution of some individual and grants her a pardon. Suppose also that a future prosecutor under the control of a subsequent President believes a prosecution of that individual for the same offense is warranted. Neither the future prosecutor nor the judiciary can strike down or ignore the pardon on the grounds that the previous President misread the Constitution. One might question why the judiciary (or the future President) should be forced to adhere to the constitutional reasonings of the earlier President. But that is the wrong question. When the judiciary permits the defendant to raise the pardon as a defense, the judiciary does not thereby acquiesce to the prior President's constitutional interpretations. Instead the judiciary accords to the 
pardon the power that the Constitution assigns to it - the power to prevent prosecution and punishment.

The same is true for judgments. When the judiciary issues a judgment, others must regard it as the final disposition of a dispute. When the executive branch enforces a judgment, it performs a timehonored executive function. In fact, to allow the executive branch to decline to enforce judgments at its own discretion might functionally transfer the authority to decide Article III cases or controversies to the President. A duty to enforce judgments does not mean that executive branch officers acquiesce in the constitutional readings underlying the judgment. One can enforce judgments even if one completely disagrees with the readings that lead to them.

Is judgment supremacy but a hop, skip, and a jump away from interpretive supremacy? Won't presidents and Congress grow tired of taking executive and legislative action based on their independent constitutional interpretations when they predictably will lose before a court? Why bother with interpretive independence when acknowledging interpretive supremacy will help you win more cases in court?

We do not believe that judgment finality inevitably leads to interpretive supremacy, any more than pardon finality leads to presidential supremacy. Because Congress and the President resolve many more questions of constitutional law, any acquiescence to interpretive supremacy for the courts must stem not from the consequences of judgment supremacy, but from something else. That something else might be a desire to devote time and resources to solving more pressing social problems for which electoral rewards may be higher. Or it might be a desire to avoid responsibility for having to resolve difficult constitutional questions for which many people hold intense, but conflicting, preferences.

All this raises the question of what to do with judgments so far beyond the pale that most if not all would blanch at their enforcement. One is tempted to say that the Constitution somehow permits the President to ignore "crazy judgments" or judgments based on "crazy constitutional interpretations." But we will not give into this temptation. We believe the Constitution calls upon the President to enforce every judgment. We suspect that the founders never contemplated what to do when the judiciary issues completely unfounded judgments. They did grant the President plenary powers to counteract some extreme examples of oppression by the judiciary. So, for example, if the judiciary were to issue a judgment simply imprisoning someone without trial, the President has the power to pardon that person. But beyond pardons, the Framers did not explicitly grant the President the right to "review" judgments, and established instead the familiar rule of executive enforcement of 
judgment. Presidential refusal to implement judgments is an extraconstitutional measure that ought to be reserved for only the most grave circumstances.

\section{CONCLUSION}

What has been lacking in the recent surge of works calling for an end to judicial review is a sense of proportion. These works seem to argue that in order to end unwarranted judicial supremacy we must end judicial review. Apparently, Kramer believes the American people should return to mobbing; the only significant mobbing that appears to happen these days is in response to sporting events. A Tushnet, ${ }^{76}$ or a Post and Siegel, ${ }^{77}$ seem equally unrealistic in suggesting ways to take the Constitution away from the courts and to return it to Congress. At times, critics seem to hope that the courts themselves will repudiate judicial supremacy, something that appears extremely unlikely given the course of decisions over the past decade.

We have a different proposal, one that builds upon our vision of the way in which the people can interpret the Constitution through methods endogenous to the Constitution. We agree with the Court's critics that our President, Congress, and courts should move away from the prevailing system of judicial supremacy in interpreting the Constitution. We think they are wrong, however, in calling for an end to judicial review in order to achieve that end. This is akin to arguing that we can preclude presidential interpretive supremacy by eliminating the veto power. Rather, we think the people should use the usual political processes created by the Constitution to restore departmentalism in constitutional interpretation. This could be done fairly easily through the judicial appointments process. The President simply could choose to nominate only those who agree that judicial interpretation of the Constitution is not binding on the other branches, and that each branch has the authority to interpret the Constitution when executing its own constitutional functions. The Senate could adopt this litmus test as well. Rather than merely worrying about whether a nominee is a strict constructionist or a follower of the living Constitution approach, both political parties could agree to nominate and appoint departmentalists.

This would create a very different, but we think welcome, change in the current appointments process. ${ }^{78}$ Currently, presidents and

76. TUSHNET, supra note 35 , at 175.

77. See, e.g., Robert C. Post \& Reva B. Siegel, Legislative Constitutionalism and Section Five Power: Policentric Interpretation of the Family and Medical Leave Act, 112 YALE L.J. 1943, 1946 (2003).

78. The commentary on the Supreme Court appointments process is vast. For leading works, see Bruce A. Ackerman, Transformative Appointments, 101 HARV. L. REV. 1164 
senators seem to be engaged in a delicate dance to outmaneuver each other. Presidents choose among candidates who share their judicial philosophy, which can range from satisfying a simple litmus test (such as supporting the right to abortion) to a general approach to interpretation (such as adhering to the Constitution's original understanding). They then seek to nominate an individual whose paper record will not suggest that he or she shares extreme versions of the President's legal approach. Supreme Court nominees look forward to a grilling on their views on specific issues of importance to various interest groups. Senators devote their questions toward trying to ferret out a nominee's views, and might reject one whose views lie outside those of the median senator. Nomination hearings become a struggle between nominees who do not wish to pre-judge issues by committing to certain outcomes before they even reach the bench, and senators who want to pin them down on specific cases and doctrines.

Our theory of departmentalism recommends a different approach. Rather than merely investigating a nominee's theories on constitutional interpretation or worrying whether a nominee would reach a specific outcome on a certain question, presidents and senators might agree to appoint nominees who did not believe in judicial supremacy. This might have several salutary effects. First, the judges themselves might become more respectful of the other branches' responsibility to interpret the Constitution. Second, Presidents and congresses might take their obligation to interpret the Constitution more seriously, and they might become more confident that they can act on their understandings. Third, it would have the healthy effect of repairing our broken judicial appointments process. Under a system of judicial supremacy, the judicial appointments process inevitably came to resemble political campaigns. If the Court has the final say on questions ranging from abortion to affirmative action to gay rights, the only way for groups interested in changing national policy on these questions is to alter the personnel on the Court. Under a system of judicial supremacy, control of Court appointments becomes one of the great political prizes in the contest over social policy.

Finally, coordinate constitutional review would return at least some control over national policy on these highly contested issues to the political process. Efforts to change national policy would not only

(1988); John O. McGinnis, The President, the Senate, the Constitution, and the Confirmation Process: A Reply to Professors Strauss and Sunstein, 71 TEX. L. REV. 633 (1993); Henry Paul Monaghan, The Confirmation Process: Law or Politics?, 101 HARV. L. REV. 1202 (1988); David A. Strauss \& Cass R. Sunstein, The Senate, the Constitution, and the Confirmation Process, 101 YALE L.J. 1491 (1992); Symposium, Confirmation Controversy: The Selection of a Supreme Court Justice, 84 Nw. U. L. REV. 832 (1990); John C. Yoo, Choosing Justices: A Political Appointments Process and the Wages of Judicial Supremacy, $98 \mathrm{MICH}$. L. REV. $1436(2000)$. 
seek change through the courts, but through the political branches. With coordinate-branch constitutional review, there would be three separate power centers for interpreting the Constitution, not just one. Political actors could then change constitutional interpretation in multiple ways, rather than only through the personnel of the Supreme Court. A party dissatisfied with the Court's decisions on abortion or affirmative action could seek their desired policy through executive orders or legislation, rather than through judicial decisions. While the judiciary would continue to issue judgments based on their reading of the Constitution, judges would abandon all pretenses that they are superior interpreters of the Constitution and that they are the Constitution's final arbiters.

We do not wish to overclaim. Requiring interpretive humility from prospective nominees to the courts is hardly a panacea. The ultimate way of ending the judiciary's interpretive supremacy is to have the other branches and the people regain confidence in their own ability to interpret the Constitution. By accepting the seductive view that the courts may establish the Constitution's meaning for everyone else, the political branches have shirked their responsibilities. If the political branches (and the public) can shed the habit of deciding what the Constitution means almost solely by reference to what the courts have said, we will have gone a long way to ending interpretive supremacy. 